\title{
Organizational Culture and Demographic Characteristics of Employees
}

\author{
Lütfi SÜRÜCÜ iD a Dilek SÜRÜCÜ iD b \\ a European Leadership University, Famagusta, TRNC. 1utfi.surucu@elu.edu.tr \\ b Ministry of Youth and Sports, Ankara, Turkey. dilek.zaman@gsb.gov.tr
}

\begin{tabular}{|c|c|}
\hline ARTICLE INFO & ABSTRACT \\
\hline $\begin{array}{l}\text { Keywords: } \\
\text { Organizational culture } \\
\text { Demographic factors } \\
\text { Innovative culture } \\
\text { Community culture } \\
\text { Competive culture }\end{array}$ & $\begin{array}{l}\text { Purpose - Organizational culture is a driving force that positively affects the performance of the } \\
\text { organization by shaping employee behavior. The literature states that culture is influenced by } \\
\text { various factors and it is difficult to create a monolithic organizational culture. In this context, it is } \\
\text { important to discover the factors that affect organizational culture. The main purpose of this research } \\
\text { is to reveal how demographic features affect the perception of organizational culture and to expand } \\
\text { the literature on this culture. }\end{array}$ \\
\hline $\begin{array}{l}\text { Received } 10 \text { February } 2020 \\
\text { Revised } 19 \text { April } 2020\end{array}$ & $\begin{array}{l}\text { Design/methodology/approach - The data were obtained from } 156 \text { factory employees operating in } \\
\text { Izmit. The data collected by the survey method were analyzed using IBM SPSS } 23 \text { statistical } \\
\text { software. }\end{array}$ \\
\hline Accepted 4 May 2020 & $\begin{array}{l}\text { Findings - The results of the analysis show that employees' perceptions of organizational culture; It } \\
\text { shows that it changes according to gender, age, marital status, work experience and working time } \\
\text { with the same manager. }\end{array}$ \\
\hline & $\begin{array}{l}\text { Discussion - It is considered that the results of the research will guide the managers on diversity } \\
\text { management. }\end{array}$ \\
\hline
\end{tabular}

\section{Introduction}

Today, organizations operate in an environment characterized by extraordinary global changes (Maslakçı \& Şeşen, 2019). This puts organizations in a struggle to survive and gain competitive advantage in an economic market based on changing customer demands, rapid technical changes and global knowledge (Misigo et al., 2019).

Considering today's competitive environment, in order to achieve organizational success, organizations must have a strong organizational culture as well as efficient use of resources (Schein, 2011). Organizational culture is one of the most important factors affecting organizational performance, and in the literature, many researchers state that success-oriented organizational culture increases organizational performance (Bourdeau et al., 2018; Misigo et al., 2019). Due to its importance, organizational culture has attracted the attention of many researchers and researches on organizational culture providing organizational success have increased in the last 30 years (Sürücü \& Yeşilada, 2017).

Past empirical researchs show that organizational culture helps employees do their jobs efficiently and effectively (Taşdemir et al., 2019). However, creating an organizational culture that will serve the success of the organization is still a challenging process for many organizations because the organizational culture is affected by many internal and external factors. This difficulty arises from the diversity of the demographic characteristics of each employee who make up the organizational culture. Although organizations need this diversity to be more creative and open to change, this existing diversity is also difficult to manage (Ledimo, 2015). Organizations that can manage diversity gain an important competitive advantage by creating a productive working environment for their employees (Mazur, 2010). In order to gain competitive advantage and achieve success, it will be useful to understand the factors that affect organizational culture.

The current literature states that the demographic characteristics of the employees play a key role in the formation of organizational culture perceptions (Hofstede et al., 1990; Helms \& Stern, 2001). Being aware of the effects of demographic features on the perception of organizational culture, organizing organizational 
policy, determining competencies and planning manpower leads human resources managers (Sayli et al., 2010). However, understanding the impact of individual differences between employees on cultural perceptions facilitates diversity management and forms the basis of organizational success (Ledimo, 2015). For this reason, the study examined how individual differences of employees affect their perceptions of organizational culture.

Our research consists of 3 parts. The first section is the literature on organizational culture and demographic features, the second section is the discussion and conclusion section created in line with the analysis of the data and the last section is based on the findings obtained.

\section{Literature}

\section{Organization Culture}

Organizational culture consists of values, beliefs and norms shared by employees. Organizational culture, which is the determining factor in the organization's success and failure, is seen as a potential resource and organizational capital in providing a sustainable competitive advantage (Crous \& Scheel 2007). However, organizations frequently use organizational culture to motivate their employees in order to increase the efficiency and performance of the organization (Jackalas et al., 2016). Because of its importance, organizational culture is a frequently researched subject. Over the past 30 years, the theoretical network has expanded in relevant researches on organizational culture, but a conceptually accepted definition has not been established. Although different definitions are made, many researchers agree that organizational culture means the system of values, beliefs and behaviors shared among employees (Belias \& Koustelios 2014a). Considering the facts that researchers agree on organizational culture, we can say that organizational culture is a compass that directs and shapes the institution.

When the literature on organizational culture is examined, it is seen that many classifications are made. Each researcher examined the organizational culture from different perspectives and made different classifications. Cameron and Quinn (1999), one of the most important researchers on organizational culture, focuses on the subject by taking into account the strategies of the organization and the relations between the employees; While gathering in 4 classes as adhocracy culture, clan culture, market culture and hierarchy culture, Ogbonna and Harris (2000); He made it as competitive, innovative, bureaucratic and community culture. When the definitions of cultures in these classifications are examined; It is seen that innovative and adhocracy culture, competitive and market culture, community and clan culture are similar. For this reason, three dominant organizational culture having similar characteristics with the classification of Cameron and Quinn (1999) such as innovative, competitive, community culture, was taken in the classification made by Ogbonna and Harris, (2000).

Innovative Culture: Today's organizations must face an environment characterized by changing customer demands and rapid technical changes. In this environment, the survival and competitive advantage of organizations depend on their ability and flexibility to respond quickly to changes. Innovative culture is a type of the organizational culture that enables the organization to adapt to this rapidly changing environment. In this context, innovative culture is about increasing organizational performance and maintaining competitive advantage (Lyon \& Ferrier, 2002). The literature considers Innovative culture as a critical source of competitive advantage in a changing and diverse competitive environment and sees it as an existential resource for the success of organizations (Dess \& Picken, 2000).

Innovative culture emphasizing development of new products and services, growth, change and productivity is a developmental organizational culture (Tseng, 2010). The main purpose of such a culture is to harmonize the organization with the changing competitive environment and to ensure that the organization gains competitive advantage with new products, services and configurations. Therefore, innovative culture is considered as one of the main drivers of long-term success, especially in today's dynamic markets (Nonaka et al., 2014).

Strategy of the innovative culture is; based on constant change, obtaining new information and resources, and providing different services. Thus, it enables the organization to improve its performance by producing unique and value-added products and services for organizations. Misigo et al. (2019) emphasizes the importance of innovative culture by stating that innovative culture increases the performance of the company 


\section{Sürücü - D. Sürücü 12/2 (2020) 1046-1057}

in its research on water companies in Kenya. Due to its importance, today's organizations are in an effort to adopt innovative culture and increase it within the organization.

Competive Culture: Innovative culture facilitates the formation of acompetiveculture as it supports the creation of innovation that enables the organization to be successful in the market. From this perspective, organizations with innovative culture seem likely to have a competiveculture at the same time (Gansuwan \& Siribunluechai, 2011).

The competiveculture is more task-oriented and offers its employees a specific work program in order to achieve high goals. It values productivity, competitor spirit, and perfect work. Organizations with this culture analyze the environmental conditions and create competitive strategies by placing their attention in a competitive spirit without losing their effectiveness. The main goal for organizations with competitive is to increase the market share and profitability by providing superiority in the competition in the market (Mwangi et al., 2018). Success is indispensable in this culture and the main factor that maintains the integrity of the organization is winning (Dastmalchian et al., 2000).

The competiveculture, whose main feature is to achieve competitive power, is control-oriented and focuses on external factors. In contrast to the competiveculture, community culture, whose main characteristics are corporate loyalty and employee participation, focuses on internal organization (Zafar et al., 2016). Although externally oriented organizations seem to gain competitive advantage compared to internally oriented organizations (Baker \& Sinkula, 2007), they can provide competitive advantage in organizations with community culture compared to the market where organizations are located.

Community Culture: Community culture emphasizes the development of common values and goals within the organization and it is aimed to increase the performance by creating these values. Community culture provides collective decision and consensus within the organization, reduces strategic role conflict and the resistance of employees to change (Moorman, 1995). Thus, adaptation to the changing competitive environment becomes easier. Compared with the traditional bureaucratic management approach, its decentralized structure provides a more effective form of control in highly ambiguous or constantly changing environments (Chuang et al., 2012). However, the trainings offered to the employees and the coaching by their leaders affect the performance of the organization positively. The literature makes it clear that valuing and motivating employees will increase loyalty in employees so that organizational performance can be improved (Mwangi et al., 2018).

In this culture, there is sharing, people-oriented development and a decision-making mechanism that includes everyone. Thus, shared values, traditions and beliefs provide consensus amongst employees against common goals. The main phenomenon that keeps employees together is the common vision that all employees have. Having a common vision means that the leader and the employee have the same goals and that the employees volunteer for the success of the organization. Joint organizational understanding and loyalty also increase as ideas and collaboration among employees create an environment of trust. In addition, community culture prevents possible discussions as it keeps organizational interests and employee interests at an equal distance. Cameron and Freeman (1991) state that the most appropriate culture for employees to reduce anxiety and increase morale is community culture. From this point of view, it can be said that working in organizations with community culture is a source of happiness for employees.

People working in organizations with community culture see themselves as a big family. In this culture, the interdependence and feelings of unity among the employees improve considerably. Employees adopt the organization so much that they keep the organization with them and always support each other to achieve organizational goals (Sürücü \& Yeşilada, 2017).

\section{The Relationship between Organizational Culture and Demographic Features}

Organizational culture expressing the different identity that each organization has consists of shared values, behaviors, expectations, beliefs and norms. It is a frequently researched subject because of its critical importance in ensuring organizational success. Surprisingly, most of the research on organizational culture was made on the basis that culture is universally shared within the organization and will be consistent over time (Helms \& Stern, 2001). Although the organization strives to instill common values and beliefs in all its employees, it is unlikely that employees' perceptions of culture within the organization will be universal. 


\section{Sürücü - D. Sürücü 12/2 (2020) 1046-1057}

Because the perception of culture varies according to the way employees interpret the events and their reactions to these events. Indeed, recent research shows that there are both individual and institutional factors that will affect employees' perceptions of the culture of the organization (Belias \& Koustelios, 2014b; Ledimo, 2015).The first research that organizational culture is not monolithic and that employees' perceptions of organizational culture may be affected by demographic characteristics was made by Hofstede et al (1990). After the Hofstede et al (1990), the research on the effects of demographic variables on organizational culture has increased.

Helms and Stern (2001) found that nurses' cultural perceptions changed according to work experience, department, gender, age and race while Chen et al. (2008) found that organizational culture perceptions were influenced by various demographic factors such as age, education and work experience, in the study conducted by bank employees.

In another study conducted on bank employees, Belias and Koustelios (2014b) state that age and work experience differences among employees have an impact on cultural perceptions. There are studies in the literature that differences such as race, gender, age and education level are effective in the formation of cultural perceptions (Sayli et al., 2010; Ledimo, 2015). All these studies reveal that individual differences based on demographic characteristics affect perceptions of organizational culture and that there are differences between cultures perceived in the organization. In accordance with the accumulated empirical evidence and literature, the following hypothesis has been developed.

Hypothesis: Demographic differences between employees affect culture perceptions.

\section{Methods}

Whether there are differences between the demographic characteristics of the employees and the organizational culture that they perceived, was investigated by quantitative methods. Observations and interviews used as qualitative methods, are a widely accepted and frequently used method of research in determining the effect of organizational culture (Sayli et al., 2010). However, in these methods, employees may respond as expected by the observer or it may be possible for the researcher to be biased in their observations. On the other hand, quantitative methods provide explanatory and descriptive benefits for institutional research and large-scale studies. Quantitative methods allow for comparative studies in cultural studies (Tepeci, 2001). For this reason, in the research, the determination of the perceptions of the employees towards the organizational culture was made using quantitative methods and the survey method was used as a data collection tool.

\section{Data collection and sample}

Research data in Izmit (Turkey) were obtained from operating in the factory workers. Firstly, the factory manager was contacted for the research and verbal permission was obtained from him. Factory employees work in three shifts. In order to reach all employees, the research was carried out for two days and an on-site survey was applied to the employees. In order not to cause any concern for the employees, their names were not asked and it was stated that the data obtained would not be shared with third parties and used only within the scope of the research. In the factory with 253 employees; with the follow-up of 25 employees and 53 employees refusing to fill in the questionnaire, 175 personnel were surveyed. 175 questionnaires collected were examined by the researchers, 19 questionnaires, which were filled in incorrectly, were excluded from the scope of the study and the study was completed with 156 questionnaire data.The results regarding the demographic structure of the participants are presented in Table 1. 
Table 1.Demographic Features of the Participants

\begin{tabular}{|l|l|l|l|}
\hline \multicolumn{1}{|c|}{ Participants } & \multicolumn{1}{c|}{ Content } & Frequency & \multicolumn{1}{c|}{ Percentage } \\
\hline Gender & Woman & 50 & 32,1 \\
& Man & 106 & 67,9 \\
\hline Age & $<25$ & 61 & 39,1 \\
& $26-30$ & 58 & 37,2 \\
& $31-35$ & 14 & 9 \\
& $36-40$ & 14 & 9 \\
& $\geq 41$ & 9 & 5,8 \\
\hline Marital Status & Unmarried & 110 & 70,5 \\
& Married & 46 & 29,5 \\
\hline Education Level & Elementry School & 11 & 7,1 \\
& High School & 31 & 19,9 \\
& Undergraduate & 101 & 64,7 \\
& Postgraduate & 13 & 8,3 \\
\hline Work Experience & $<1$ Year & 36 & 23,1 \\
& $1-5$ Years & 85 & 54,5 \\
& $6-10$ Years & 25 & 16 \\
& $\geq 10$ & 10 & 6,4 \\
\hline Working time with the same manager & $<1$ Year & 59 & 37,8 \\
& $1-5$ Years & 83 & 53,2 \\
& 6-10 Years & 14 & 9 \\
\hline
\end{tabular}

$\mathrm{N}=156$

When the demographic characteristics of the participants are examined; it is seen that most of the employees are male $(67.9 \%)$ and single $(70.5 \%)$.

\section{Measures}

In the research, a 19-question questionnaire consisting of 2 different scales was used.

Demographic Structure: It consists of 6 questions to determine the demographic characteristics of the employees.

Organizational Culture:Related articles measuring organizational culture were examined and threedimensional, 13-item scale, developed by Ogbonna and Harris (2000) and used by Bakan (2009) in his study conducted in Turkey, was used. Scale; It measures innovative culture, competitive culture and community culture.Sample questions about the scale prepared in the 5-point Likert system; "Those who work in this business are ready to take risks.", "Managers who are productive and love hard work in this business are considered the best managers." and "This business is like a large family." Cronbach's alpha coefficient of the sub-dimensions of the scale is .73 and above.

\section{Findings}

In the research, after the numerical and percentage distribution of demographic features, analyzes were made in terms of overall structure and part reliability. Factor analysis of the organizational culture scale developed by Ogbonna and Harris (2000) was conducted and the results of the analysis show that the values reached for each factor group are statistically acceptable and suitable for other analyzes.

In reliability analysis, Cronbach's alpha coefficients of each variable were calculated by taking into account the changes made in the scales as a result of factor analysis. Accordingly, from organizational cultures; Cronbach's alpha coefficient of innovative culture was measured as .83, competitive culture .73, community culture .74. When Cronbach's alpha coefficient are analyzed, it can be said that the research variables are measured reliably. In line with the survey, various propositions are presented to determine the organizational culture perceived by the employees and the arithmetic means of the responses to these propositions are shown in Table 2. 
Table 2. Descriptive Data on Organizational Culture

\begin{tabular}{|l|c|c|c|}
\cline { 2 - 4 } \multicolumn{1}{c|}{} & $\begin{array}{c}\text { Number of } \\
\text { Questions }\end{array}$ & Mean & Std. Deviation \\
\hline Innovative Culture & 5 & 3.44 & .96 \\
\hline Competitive Culture & 4 & 3.53 & .88 \\
\hline Community Culture & 4 & 3.42 & .94 \\
\hline
\end{tabular}

When the data in Table 2 are examined; the participants of the survey generally give positive answers to the propositions about innovative, competitive and community culture types.

The Analysis shows that the data have a normal distribution (Skewness $=0.214$, Kurtois $=0.834$ ). Therefore; parametric tests were used in the analysis. T-test and One-Way Anova tests were conducted to determine whether the organizational culture differentiated by the participants according to their demographic characteristics differentiated. Participants; In the analysis made considering gender, marital status, age, education status, working time at the workplace and working time with the manager, it is seen that the perception of organizational culture differs according to certain situations.

t-test was conducted to determine if the organizational culture perceived according to gender has differentiated and the results are presented in Table 3.

Table 3. t-test: Gender

\begin{tabular}{|c|c|c|c|c|c|c|c|}
\hline & Gender & $\mathbf{n}$ & Mean & Sd & $\mathbf{t}$ & $\mathrm{p}$ & Results \\
\hline \multirow{2}{*}{ Innovative Culture } & Man & 50 & 3.55 & .962 & \multirow{2}{*}{1.119} & \multirow{2}{*}{.144} & \\
\hline & Women & 106 & 3.41 & .926 & & & \\
\hline \multirow{2}{*}{ Competitive Culture } & Man & 50 & 3.68 & .863 & \multirow{2}{*}{2.387} & \multirow{2}{*}{$.008^{* *}$} & \multirow{2}{*}{$a-b$} \\
\hline & Women & 106 & 3.41 & .825 & & & \\
\hline \multirow{2}{*}{ Community Culture } & Man & 50 & 3.52 & .927 & \multirow{2}{*}{1.182} & \multirow{2}{*}{.238} & \\
\hline & Women & 106 & 3.37 & .940 & & & \\
\hline
\end{tabular}

${ }^{* *} p<0,05$ ( $a$ : Man b: Women)

The results of the t-test analysis, whether the perceptions of innovative culture and community culture are different from men and women; shows that the variances are homogeneous and there is no significant difference between the mean values of women and men $(t=1.119, t=1.182, p>.05)$. However, there is a significant difference between perceptions of competitive culture by gender $(t=2.387, p<.05)$. This shows that men are more competitive than women and competitive culture perceptions are higher than women.

A t-test was conducted to determine whether the organizational culture perceived according to marital status differentiated and the results are presented in Table 4.

Table 4. t-test: Marital Status

\begin{tabular}{|c|c|c|c|c|c|c|c|}
\hline & $\begin{array}{l}\text { Marital } \\
\text { Status }\end{array}$ & $\mathbf{n}$ & Mean & Sd & $\mathbf{t}$ & $\mathrm{p}$ & Results \\
\hline \multirow{2}{*}{ Innovative Culture } & Married & 46 & 3.32 & & \multirow{2}{*}{-2.056} & \multirow{2}{*}{$.041^{* *}$} & \multirow{2}{*}{$a-b$} \\
\hline & Single & 110 & 3.58 & .942 & & & \\
\hline \multirow{2}{*}{ Competitive Culture } & Married & 46 & 3.39 & .903 & \multirow{2}{*}{-2.541} & \multirow{2}{*}{$.012^{* *}$} & \multirow{2}{*}{$a-b$} \\
\hline & Single & 110 & 3.69 & .835 & & & \\
\hline \multirow{2}{*}{ Community Culture } & Married & 46 & 3.45 & .884 & \multirow{2}{*}{-.315} & \multirow{2}{*}{.753} & \\
\hline & Single & 110 & 3.49 & .949 & & & \\
\hline
\end{tabular}

${ }^{*} p<0,05$ ( a: Married, $b$ : Single) 


\section{Sürücü - D. Sürücü 12/2 (2020) 1046-1057}

The results of the t-test analysis, whether the perceptions of innovative cultures differ according to the marital status of the participants; The innovative culture perceptions show that there is a significant difference $(t=-$ $2.056, \mathrm{p}<.05)$ compared to married and single participants and their variances are homogeneous. Accordingly, it can be said that the innovative culture perception of married participants is higher than that of single participants. Whether the competitive culture perceptions differ according to the marital status of the participants, the results of the t-test analysis; Competitive culture perceptions show that there is a significant difference $(\mathrm{t}=-2.541, \mathrm{p}<.05)$ compared to married and single participants, and variances have homogeneous features. Accordingly, competitive culture perceptions of married participants are higher than single participants. The results of the $t$ test analysis for the community culture show that the fact that the participants are married or single does not make any difference in their perception of community culture.One-Way Anovaanalysis results, which are conducted to determine whether there is a difference in cultural perceptions according to age groups, are presented in Table 5.

Table 5. One-Way Anova analysis results regarding the comparison of organization culture by age groups of participants

\begin{tabular}{llllllll}
\hline & Age & M & Mean & Sd & F & p & Results \\
& Groups & & & & & \\
\hline & $\leq 25$ & 61 & 3.61 & .916 & 1.269 & .282 & \\
Innovative Culture & $26-30$ & 58 & 3.43 & .971 & & \\
& $31-35$ & 14 & 3.70 & 1.043 & & \\
& $36-40$ & 14 & 3.36 & 1.021 & & \\
Competitive Culture & $\geq 41$ & 9 & 3.14 & .760 & & \\
& $\leq 25$ & 61 & 3.70 & .817 & 3.551 & $.004^{*}$ & a-e \\
& $26-30$ & 58 & 3.64 & .851 & & & b-e \\
& $31-35$ & 14 & 3.50 & .825 & & \\
& $36-40$ & 14 & 3.47 & 1.081 & & \\
& $\geq 41$ & 9 & 2.70 & .695 & & & \\
\hline & $\leq 25$ & 61 & 3.74 & .844 & 6.652 & $.005^{* *}$ & a-b \\
& $26-30$ & 58 & 3.23 & .945 & & & a-e \\
& $31-35$ & 14 & 3.78 & .823 & & c-e \\
& $36-40$ & 14 & 3.25 & 1.124 & & \\
& $\geq 41$ & 9 & 2.95 & .562 & & \\
\hline
\end{tabular}

** $p<0.05$ ( $a: 25$ years and under, $b: 26-30$ years, $c: 31-35$ years, $d: 36-40$ years, $e: 41$ years and above)

Hochberg's GT2, which is one of the Post Hoc tests, was used in the One-Way Anova analysis conducted to determine whether there was a difference in the competitive culture perceptions of the participants according to age groups. In line with the findings obtained according to the analysis results; In the comparison between the age group " 25 and under" and the age group " 41 and above" in favor of the age group " 25 and under", in the comparison between the age group "26-30" and the age group "26-30" there is a significant difference in favor of the group. From this point of view, it is understood that the employees in the young age group have a higher perception of competitive culture than those in the " 41 and over" age group. In other words, it is seen that young employees have more competitive spirit and attach importance to success.

In the One-Way Anova analysis conducted to determine whether there is a difference in the perception of the community culture according to the age groups of the participants, Games-Howel, one of the Post Hoc tests, was applied because the variances were not homogeneous. In line with the findings obtained according to the analysis results; There is a significant difference in favor of the " 25 and under" age group compared to the 


\section{Sürücü - D. Sürücü 12/2 (2020) 1046-1057}

"26-30" age group and the " 41 and above" group of the " 25 and under" age group. In addition to these findings, there is a significant difference in favor of the "31-35" age group compared to the "31-35" age group and the " 41 and above" age group. From this point of view, it is understood that the employees in the young age group have a high sense of community culture.

As the results of One-Way Anova analysis regarding the comparison of organization culture according to the education levels of the participants were not significant, Post Hoc test was not performed.

One-Way Anovatest was performed to determine whether there is a difference in cultural perceptions of the participants' working time at the workplace and the results are shown in Table 6.

Table 6. Organization One-Way Anova analysis results regarding the comparison of culture according to the working time of the participants.

\begin{tabular}{|c|c|c|c|c|c|c|c|}
\hline & $\begin{array}{l}\text { Working } \\
\text { Time }\end{array}$ & $\mathbf{n}$ & Mean & Sd & $\mathbf{F}$ & p & Results \\
\hline \multirow{4}{*}{ Innovative Culture } & $1>$ & 36 & 3.48 & 1.021 & 4.919 & $.002^{* *}$ & b-e \\
\hline & $1-5$ & 85 & 3.61 & .948 & & & d-e \\
\hline & $6-10$ & 25 & 3.68 & .755 & & & \\
\hline & $\geq 10$ & 10 & 2.70 & .741 & & & \\
\hline \multirow{4}{*}{ Competitive Culture } & $1>$ & 36 & 3.66 & .107 & 8.032 & $.000^{* * *}$ & $a-d$ \\
\hline & $1-5$ & 85 & 3.74 & .620 & & & $b-c$ \\
\hline & $6-10$ & 25 & 3.34 & .133 & & & $b-d$ \\
\hline & $\geq 10$ & 10 & 2.66 & .725 & & & \\
\hline \multirow{4}{*}{ Community Culture } & $1>$ & 36 & 3.36 & 1.017 & 2.272 & .547 & \\
\hline & $1-5$ & 85 & 3.59 & .911 & & & \\
\hline & $6-10$ & 25 & 3.40 & .813 & & & \\
\hline & $\geq 10$ & 10 & 3.02 & .882 & & & \\
\hline
\end{tabular}

${ }^{* *} p<0,05,{ }^{* * *} p<0,001$, (a: 1 year and under, $b: 1-5, c: 6-10, d: 10$ years and above)

In the One-Way Anova analysis conducted to determine whether there is a difference in innovative culture and competitive culture perceptions according to the working time of the participants in the research, Hochberg's GT2, which is one of the Post Hoc tests, was applied due to the homogeneous variances. In line with the findings obtained according to the analysis results;

In the workplace, in the comparison between employees with "1-5 years" work experience and employees with "10 years and above" work experience; There is a significant difference in favor of employees with " $1-5$ years" work experience. In addition, in the comparison between the employees with "6-10 years" work experience and those with " 10 years and above" work experience, it has been found that there is a significant difference in favor of employees with "6-10" years work experience. In line with these findings, we can say that young employees are more open to change, are more willing to obtain new information and provide different services.

According to the research findings, the competitive culture perception of employees with a work experience of less than 1 year is higher in the comparison between those who have a work experience of 1 year or less and those who have a work experience of "10 years or more". It seems that in comparasion with employees with "6-10 years" and "10 years and over" work experience; Employees with 1-5 years of work experience have more "competitive culture" perceptions. There appears to be a difference. In line with these findings, it can be said that those working 5 years or less are more competitive and adopt a competitive culture. 


\section{Sürücü - D. Sürücü 12/2 (2020) 1046-1057}

One-Way Anovatest was carried out with the managers of the participants in order to determine whether there is a difference in their perceptions of culture and the results are shown in Table 7.

Table 7. One-Way Anova analysis results regarding the comparison of organizational culture participants with their managers and working time

\begin{tabular}{llllllll}
\hline & Working & & & & & & Results \\
& Time & $\mathbf{n}$ & Mean & Sd & $\mathbf{F}$ & $\mathbf{p}$ & \\
\hline \multirow{2}{*}{ Innovative Culture } & $1>$ & 73 & 3.39 & 1.016 & 4.233 & $.015^{* *}$ & $\mathrm{c}-\mathrm{a}$ \\
& $1-5$ & 50 & 3.53 & .924 & & & $\mathrm{c}-\mathrm{b}$ \\
& $6-10$ & 33 & 3.97 & .694 & & & \\
\hline \multirow{2}{*}{ Competitive Culture } & $1>$ & 73 & 3.59 & .880 & .121 & .886 \\
& $1-5$ & 50 & 3.62 & .847 & & & \\
& $6-10$ & 33 & 3.66 & .887 & & & \\
Community Culture & $1>$ & 73 & 3.41 & .980 & .490 & .613 & \\
& $1-5$ & 50 & 3.53 & .916 & & & \\
\hline
\end{tabular}

${ }_{* *} p<0,05$, ( $a: 1$ years and under, $b: 1-5$ years, $c: 6-10$ years)

Within the scope of the study, the participants were asked to work with their managers and the group "over 10 years" was not included in the study since there was no participant working with the same manager for more than 10 years. Hochberg's GT2, one of the Post Hoc tests, was applied in the One-Way Anova analysis to determine whether the working time of the participants with the same manager would make a difference in the employees' innovative culture perceptions.

In the comparison between the employees between "6-10 years" with the same manager and those under " 1 year" and "1-5 years", it is seen that there is a difference in favor of the employees with the same manager between "6-10 years". In line with these findings, we can say that the innovative culture perception of employees working with the same manager between "6-10 years" is high.In addition to these findings, it was determined that the perceptions of the competitive culture and community culture of the participants did not change depending on the working time with the same manager.

\section{Discussion}

In literature, organizational culture has been associated with various demographic factors such as age, gender, and work experience. In general, our results show that the culture they perceive has changed according to the demographic characteristics of the participants. These findings support Ledimo's (2015) suggesting that individual differences lead to the creation of subcultures in the organization. The main findings are as follows.

Research results show that the perception of culture changes according to the gender of the employees. Past studies examining organizational culture in the context of gender indicate that men want to maintain their dominant power positions and are socialized to solve their problems (Holt \& DeVore, 2005). On the other hand, women socialize to deal with other people and meet their needs (Belias \& Koustelios, 2014a). In addition, women are encouraged by their parents to behave constantly and with respect (Bellou, 2010). This can be cited as a reason why male employees are more competitive than women. Another reason is that men welcome career development opportunities within the organization. Men are more ambitious and struggling to get these opportunities (Bellou, 2010). Women, on the other hand, are concerned with equal opportunities and do not want to behave differently from others. This finding obtained in the study is in parallel with Belias and Koustelios (2014a), and Bellou (2010) studies.

Considering the demographic characteristics of the age, it is seen that young employees perceive the dominant organizational culture type in different ways than the elderly. The results of the research show that young employees prefer a more competitive working environment, while older employees prefer a mutually 
relational and more intimate working environment. Especially the fact that employees aged 41 and above rely on their experience at the workplace and that they are in higher level job positions are effective in this result. Findings regarding age factor by Belias and Koustelios, (2014b), Chen et al. (2008) and Ledimo (2015) support their research.

Besides age, employees' perceptions of organizational culture vary according to their marital status. The results of the research show that married participants have higher perceptions of competitive and innovative culture compared to single participants. This finding means that married participants are more competitive and more innovative for organizational success.

When the effect of the work experience of the employees on the perception of culture is controlled, the result of the research shows that the newly recruited employees are more open to change and are more willing to offer different services. In addition to these results, employees with little work experience are more competitive than those who have been in this workplace for a long time and their perception of competitive culture is higher. This finding means that employees who spend more time in the same firm prefer a stable working environment within the organization. This finding obtained in the study is in line with the findings of Helms and Stern (2001).

Another important finding of the research is that employees' perceptions of both current and preferred organizational culture are affected by working time with the same manager. Especially, it is seen that employees working with the same manager for 6-10 years have a more innovative culture. In fact, this result is very interesting. Because the research findings have shown that new recruits are more open to change, more willing to obtain new information and provide different services. From this perspective, it is unlikely that employees between 6-10 years will have an innovative culture. The main reason for this result is that the employees working for a long time with the same manager having a common background and experience with the manager, allowing the employee to communicate more easily with the manager and spend more time. Thus, in addition to benefiting from the knowledge and expertise of the employee manager, he gets more opportunities to discuss his innovative ideas (Sürücü \& Sesen, 2019). These gains increase the motivation of the employee to be innovative and allow him to adopt an innovative culture. However, the strong relationship and interaction with the manager creates a sense of trust in the employees. Considering the uncertainty and risk of the nature of innovative behaviors, it is natural for employees who feel safe to adopt innovative culture (Sürücü \& Sesen, 2019). This finding shows that the ease of communicating with the manager and the tolerance shown by the manager contribute to the formation of an innovative culture in the employees.

\section{Result}

These findings obtained as a result of the research provide a different model regarding the factors affecting the perceptions of employees about organizational culture. As a matter of fact, management theorists state that organizational culture is not monolithic and different perceptions of culture may occur within the organization. Therefore, it is not surprising that cultural perceptions differ according to demographic characteristics. The important thing is to admit that there may be different subcultures perceived within the organization due to the demographic diversity within the organization, even if superior effort are shown. In fact, this demographic diversity of the organization has several benefits, such as increasing the sensitivity of the organization to changes and facilitating the solution of internal problems. However, it is difficult to manage this intra-organizational diversity. HR managers need to manage this diversity in order to create the right organizational culture that will help the company achieve positive financial results. It is considered that these findings will guide HR managers in diversity management.

\section{Limitations}

Considering that the research is conducted on a single sector, it is not possible to generalize the research results to other sectors. It is likely that different results will be obtained in the researches especially for the service sector. Because the service sector is based on knowledge and skills and differs among its functions. For this reason, research on a large sample in several sectors including the service sector will be more general. 


\section{Sürücü - D. Sürücü 12/2 (2020) 1046-1057 \\ References}

Bakan, İ. (2009). Liderlik Tarzları ile Örgüt Kültürü Türleri Arasındaki İlişkiler: Bir Alan Çalışması. TISK Academy/TISK Akademi, 4(7).

Baker, W. E. \& Sinkula, J. M. (2007). Does market orientation facilitate balanced innovation programs? An organizational learning perspective. Journal of Product Innovation Management, 24(4), 316-334.

Belias, D. \& Koustelios, A. (2014a). Organizational culture and job satisfaction: A review. International Review of Management and Marketing, 4(2), 132-149.

Belias, D. \& Koustelios, A. (2014b). The influence of demographic characteristics of Greek bank employees on their perceptions of Organizational Culture. International Journal of Human Resource Studies, 4(1), 81.

Bellou, V. (2010). Organizational culture as a predictor of job satisfaction: the role of gender and age. Career Development International, 15(1), 4-19.

Bourdeau, S. Aubert, B. \& Bareil, C. (2018). Innovation Intensity: From IT Use and Innovative Culture to Organizational Performance. Innovation, 6, 26-2018.

Cameron, K. S. \& Freeman, S. J. (1991). Cultural congruence, strength, and type: relationships to effectiveness. Research in Organizational Change and Development, 5, 81-105.

Cameron, K. S. \& Quinn, R. E. (2011). Diagnosing and changing organizational culture: Based on the competing values framework. John Wiley \& Sons.

Cameron, K.S. \& Quinn, R.E. (1999).Diagnosing and Changing Organizational Culture. Based on the Competing Values Framework.Addison-Wesley, Reading, MA.

Chen, C. C., Fosh, P. \& Foster, D. (2008). Gender differences in perceptions of organizational cultures in the banking industry in Taiwan. Journal of Industrial Relations, 50(1), 139-156.

Chuang, F. M., Morgan, R. E. \& Robson, M. J. (2012). Clan culture, strategic orientation and new product performance in Chinese marketing ventures: an exploration of main and moderating effects. Journal of Strategic Marketing, 20(3), 267-286.

Crous, F. \& Scheel, R. (2007). Leveraging organisational cultural capital. SA Journal of Industrial Psychology, 33(1), 29-37.

Dastmalchian, A., Lee, S. \& Ng, I. (2000). The interplay between organizational and national cultures: a comparison of organizational practices in Canada and South Korea using the Competing Values Framework. International Journal of Human Resource Management, 11(2), 388-412.

Dess, G. G. \& Picken, J. C. (2000). Changing roles: Leadership in the 21st century. Organizational Dynamics, 28(3), 18-34

Gansuwan, P. \& Siribunluechai, A. (2011). The Interrelationship ofthe Market-Driving Approachand the Organizational Culture: A qualitative study of the market-driving companies.

Helms, M. M. \& Stern, R. (2001). Exploring the factors that influence employees' perceptions of their organisation's culture. Journal of Management in Medicine, 15(6), 415-429.

Hofstede, G., Neuijen, B., Ohayv, D. D. \& Sanders, G. (1990). Measuring organizational cultures: A qualitative and quantitative study across twenty cases. Administrative science quarterly, 286-316.

Holt, J. L. \& DeVore, C. J. (2005). Culture, gender, organizational role, and styles of conflict resolution: A metaanalysis. International Journal of Intercultural Relations, 29(2), 165-196.

Jackalas, M. B., Martins, N. \& Ungerer, L. M. (2016). The impact of demographic variables on organisational culture and employee motivation: evidence from a health insurance company in Botswana. Journal of Contemporary Management, 13(1), 357-384.

Ledimo, O. (2015). Diversity management: An organisational culture audit to determine individual differences. Journal of Applied Business Research (JABR), 31(5), 1733-1746. 


\section{Sürücü - D. Sürücü 12/2 (2020) 1046-1057}

Lyon, D. W. \& Ferrier, W. J. (2002). Enhancing performance with product-market innovation: the influence of the top management team. Journal of Managerial Issues, 452-469.

Maslakçı, A. \& Şeşen, H. (2019). Multicultural Personality Traits and Employee-Perceived Service Quality in the Hospitality Industry: the Mediating Role of Cross-Cultural Psychological Capital. Revista de Cercetaresi Interventie Sociala, (65), 60-81.

Mazur, B. (2010). Cultural diversity in organisational theory and practice. Journal of intercultural management, 2(2), 5-15.

Misigo, G. K., Were, S. \& Odhiambo, R. (2019). Influence of adhocracy culture on performance of public water companies in Kenya. International Academic Journal of Human Resource and Business Administration, 3(5), 84-103.

Moorman, C. (1995). Organizational market information processes: cultural antecedents and new product outcomes. Journal of Marketing Research, 32(3), 318-335.

Mwangi, A. K., Rotich, G., Nzulwa, J. \& Orwa, G. (2018). Influence of adhocracy culture on performance of the listed banks in Kenya. Journal of Advances in Social Science and Humanities, 4(6), 56-71.

Nonaka, I., Kodama, M., Hirose, A. \& Kohlbacher, F. (2014). Dynamic fractal organizations for promoting knowledge-based transformation-A new paradigm for organizational theory. European Management Journal, 32(1), 137-146.

Ogbonna, E. \& Harris, L. C. (2000). Leadership style, organizational culture and performance: empirical evidence from UK companies. International Journal of Human Resource Management, 11(4), 766-788.

Sayli, H., Baytok, A. \& Soybali, H. H. (2010, June). The effects of employees' demographic characteristics on the perception of organizational culture: A study in service enterprise. In 2nd International Symposium on Sustainable Development (pp. 198-204).

Schein, E. (2011). Organizational culture and Leadership. (3-d edition). San Francisco: Jossey-Bass.

Sürücü, L. \& Sesen, H. (2019). Entrepreneurial behaviors in the hospitality industry: Human resources management practices and leader member exchange role. Revista de CercetaresiInterventieSociala, 66. 114132.

Sürücü, L. \& Yeşilada, T. (2017). The impact of leadership styles on organizational culture. International Journal of Business and Management Invention, 6(8), 31-39.

Taşdemir, D. D., Çekmecelioğlu, H. G. \& Yıkılmaz, İ. (2019). Çok kültürlü ortamda çalışanların kültürel zekâ düzeylerinin duygusal emek gösterimlerine etkisi. OPUS Uluslararası Toplum Araştırmaları Dergisi, 12, $1-1$.

Tepeci, M. (2001). The effect of personal values, organizational culture, and person-organization fit on individual outcomes in the restaurant industry.

Tseng, S. M. (2010). The correlation between organizational culture and knowledge conversion on corporate performance. Journal of Knowledge Management, 14(2), 269-284.

Zafar, H., Hafeez, M. H. \& Shariff, M. N. M. (2016). Relationship between market orientation, organizational learning, organizational culture and organizational performance: mediating impact of innovation. South East Asia Journal of Contemporary Business. Economics and Law, 9(2), 40-56. 